\title{
Eksplorasi Terhadap Kemungkinan Desain Podcast Pendidikan Tinggi di Indonesia
}

\author{
Rintis Mulyani \\ Pascasarjana Ilmu Komunikasi, Universitas Indonesia \\ email: rintism9@gmail.com \\ Received: 12 Januari 2021; Revised: 26 Februari 2021; Accepted: 28 April 2021 \\ DOI: http://dx.doi.org/10.37905/aksara.7.2.381-394.2021
}

\begin{abstract}
Abstrak
Penelitian ini bertujuan untuk mengeksplorasi kemungkinan desain podcast yang dapat diaplikasikan oleh lembaga pendidikan tinggi di Indonesia. Media podcast memiliki manfaat dalam pembelajaran jarak jauh. Namun, pendidikan tinggi di Indonesia belum ada yang menggunakan podcast untuk menyampaikan materi pembelajaran. Oleh karena itu, penelitian ini mensintesikan beberapa model podcast yang dapat dipadupadankan oleh pengajar dalam membuat podcast pembelajaran. Artikel ini mengulas InterestDriven Learning Design, tipe podcast, dan jenis podcast. IDLD mengulas pembelajaran yang mengakomodasi minat siswa di luar konteks lingkungan pendidikan, tipe dan jenis podcast mengulas karakteristik podcast yang dapat dijadikan panduan saat membuat konten pembelajaran melalui podcast.
\end{abstract}

Kata kunci: Pembelajaran, Podcast, Podcast Pendidikan

\begin{abstract}
This study aims to explore the possibilities of podcast designs that can be applied by higher education institutions in Indonesia. Podcast media has benefits in distance learning. However, there is no higher education in Indonesia that uses podcasts to deliver learning material. Therefore, this research synthesizes several models of podcasts that can be mixed and matched by teachers in creating learning podcasts. This article reviews Interest-Driven Learning Design, podcast types, and podcast types. IDLD reviews learning that accommodates students' interests outside the context of the educational environment; the types and types of podcasts review podcast characteristics that can be used as a guide when creating learning content through podcasts.
\end{abstract}

Keywords: Educational Podcast, Learning, Podcast

\section{PENDAHULUAN}

Podcast adalah rekaman audio yang dapat terkirim langsung ke perangkat pengguna atau konsumen seperti komputer, laptop, atau telepon pintar (Kidd, 2012). Istilah podcast dikemukakan oleh Ben Hammersley pada tahun 2004 dalam sebuah artikel di surat kabar The Guardian. Menurut Hammersley, podcast merupakan paket digital dalam bentuk audio yang umumnya terdiri atas beberapa seri, dirilis pada kurun waktu 
atau interval tertentu dan secara otomatis muncul pada perangkat media individu ketika terhubung melalui Really Simple Syndication (RSS) (Bonini, 2015). Dari kedua definisi tersebut dapat ditarik persamaan karakteristik podcast yaitu dapat diakses secara personal di perangkat pengguna.

Penelitian mengenai podcast di Indonesia belum begitu populer, khususnya di bidang pendidikan. Penelitian-penelitian sebelumnya masih berfokus pada pemanfaatan atau penggunaan podcast dalam pembelajaran (Darwis, 2016; Rizky Widodo \& Gunawan, 2019; Soerjowardhana \& Nugroho, 2017; Wulan, 2018; Yoestara \& Putri, 2019). Padahal, penelitian-penelitian mengenai podcast di dunia sudah lebih beragam. Sejak awal perkembangan podcast pada tahun awal 2000an, yang juga berbarengan dengan teknologi Web 2.0, para guru di Amerika Serikat sudah melihat potensi kegunaan podcast sebagai media pembelajaran (Drew, 2017a). Lembaga-lembaga pendidikan di Amerika Serikat sudah banyak menggunakan podcast sebagai cara baru dalam menyampaikan materi. Namun, belum banyak institusi pendidikan resmi di Indonesia yang menyampaikan materi pembelajaran dalam bentuk podcast dan mempublikasikannya secara populer. Akibatnya, ketika awal tahun 2020 dunia dilanda wabah virus corona, para pengajar di Indonesia belum menyiapkan materi pembelajaran, khususnya podcast, yang dapat diakses secara daring.

Aktivitas pembelajaran jarak jauh diprediksi akan menjadi opsi utama untuk menghindari penularan virus yang terjadi jika pembelajaran dilakukan tatap muka. Media pembelajaran yang sudah terlaksana di Indonesia sejak perubahan bentuk Kegiatan Belajar Mengajar menjadi daring di antaranya menggunakan WhatsApp, Google Meet, maupun Zoom. Namun, pembelajaran tersebut belum berjalan efektif. Banyaknya gangguan baik dari infrastruktur maupun kesiapan siswa membuat siswa tidak memahami materi pembelajaran yang ditentukan sesuai kurikulum. Untuk mengatasi permasalahan tersebut, lembaga pendidikan tinggi perlu menyiapkan materi-materi pembelajaran yang dapat diakses siswa kapan saja dan di mana saja. Salah satu media pembelajaran yang terbukti dapat meningkatkan prestasi belajar siswa adalah podcast. Untuk dapat mencapai manfaat tersebut, perlu adanya analisis terhadap kemungkinan desain yang dapat dijadikan panduan oleh pengajar dalam menyiapkan materi pembelajaran dalam bentuk podcast.

Artikel ini bertujuan untuk mengeksplorasi desain-desain podcast dari literatur sebelumnya. Artikel ini akan mengulas beberapa desain yang bisa dipadukan dalam merancang materi, mengingat lembaga pendidikan tinggi di Indonesia belum menggunakan media podcast untuk menyampaikan materi pembelajaran. Artikel ini akan mengulas The Interest-Driven Learning Design Framework dari Edelson dan Joseph (Edelson \& Joseph, 2004) dan framework desain podcast untuk pendidikan tinggi oleh Fernandez, Salan, \& Simo (Drew, 2017b). 


\section{THE INTEREST-DRIVEN LEARNING DESIGN FRAMEWORK}

Minat atau ketertarikan siswa memiliki peranan penting dalam mendorong siswa untuk belajar di luar lingkungan sekolah (Edelson \& Joseph, 2004). Perubahan dari yang semula pembelajaran tatap muka di kelas menjadi pembelajaran jarak jauh membutuhkan keinginan kuat dari dalam diri siswa agar tetap dapat mengikuti materi. Setidaknya, terdapat empat manfaat utama minat atau ketertarikan internal siswa sebagai motivator dalam belajar. Pertama, pembelajaran yang datang dari minat diri sendiri menggambarkan keinginan alami yang membuat aktivitas belajar menjadi lebih terarah, bertahan lama, dan bahkan lebih dalam (Ann Renninger, 2000). Kedua, minat mengarahkan siswa untuk memiliki keinginan menguasai bidang tertentu (Ames, 1992). Ketiga, siswa yang memiliki ketertarikan pada tugas yang diberikan akan mau meluangkan waktu lebih lama dan memberikan usaha lebih besar (Hannover \& Kessels, 2004). Keempat, siswa yang tertarik pada bidang keilmuan tertentu dapat mengoneksikan pengetahuan yang baru diperoleh dengan pengetahuan yang lama, serta dapat mengelaborasi pengetahuan tersebut dengan lebih baik (Alexander, M.P., 1995; Ann Renninger, 2000; Schiefele, 1991).

Premis utama dari Interest-Driven Learning Design Framework (IDLDF) adalah motivasi belajar itu muncul ketika siswa mempersepsikan bahwa alasan untuk mempelajari pengetahuan atau keterampilan baru berdasarkan kegunaannya (Edelson \& Joseph, 2004). Ketika individu melihat adanya kegunaan dalam memperoleh pengetahuan atau keterampilan baru, hal ini akan memunculkan motivasi bawaan dari dalam diri untuk bejar. Kegunaan yang dimaksud adalah kegunaan otentik dari pengetahuan atau keterampilan di luar konteks lembaga atau struktur pendidikan. Pengetahuan atau keterampilan dianggap berguna bagi siswa jika ia percaya bahwa dirinya dapat menerapkan pengetahuan tersebut untuk mencapai cita-citanya di luar sistem pendidikan.

\section{Sumber Minat Belajar Berdasarkan Kegunaan}

Dalam menciptakan desain pembelajaran, pengajar perlu menciptakan motivasi siswa untuk belajar berdasarkan berbagai kegunaan dari materi yang disampaikan. Terdapat lima sumber kegunaan yang dapat dimasukkan dalam konten pembelajaran untuk memunculkan minat belajar siswa.

Kesenangan. Mengoneksikan topik pembelajaran tertentu dengan aktivitas-aktivitas yang dapat dilakukan individu di luar sekolah memunculkan kepuasan intelektual (Edelson \& Joseph, 2004). Siswa yang mengerti kegunaan topik yang diajarkan dalam meningkatkan keterampilan dia dalam melakukan hobi akan lebih berminat untuk belajar.

Kepedulian. Individu menghargai kegiatan belajar atau hasil pengetahuan atau keterampilan yang didapat jika ia merasa bahwa hal tersebut penting dan selaras dengan moralitas yang dianut dan nilai-nilai yang dijunjung tinggi (Edelson \& Joseph, 2004). Misalnya, materi tentang dampak limbah terhadap lingkungan dapat meningkatkan minat pada mereka yang peduli terhadap isu kerusakan lingkungan. Siswa akan merasa bahwa 
materi tersebut berdampak langsung pada dirinya dan menganggap bahwa materi tersebut berguna bagi kehidupannya secara langsung.

Pembentukan identitas. Individu menganggap suatu aktivitas berguna bagi dirinya jika aktivitas tersebut dapat membentuk identitas dirinya (Hannover \& Kessels, 2004). Aktivis lingkungan, pejuang hak asasi manusia, dan lainnya akan merasa materi yang diajarkan berguna jika pengajar memberi tahu bahwa materi yang diajarkan dapat memperkuat identitas siswa.

Tujuan hidup. Individu merasa butuh dan tertarik terhadap hal-hal yang dapat meningkatkan kualitas hidupnya (Hannover \& Kessels, 2004). Siswa di perguruan tinggi, yang merupakan remaja atau dewasa, membutuhkan pengetahuan atau keterampilan yang bisa diaplikasikan dalam menjalin relasi dengan orang lain atau untuk meningkatkan penghasilan.

Keingintahuan. Keingintahuan adalah motivasi untuk mendapatkan pengetahuan yang dapat menjelaskan kejadian-kejadian yang belum ia pahami dan memungkinkan siswa untuk mengonstruksikan pemahamannya mengenai fenomena tersebut (Edelson \& Joseph, 2004). Rasa ingin tahu dapat meningkat jika siswa dihadapkan pada kenyataan bahwa ilmu yang ia miliki masih jauh dari yang diharapkan. Pengajar dapat memberikan stimulus berupa pertanyaan-pertanyaan terkait materi yang diajarkan untuk meningkatkan rasa ingin tahu siswa dan menyadarkannya bahwa pengetahuan mereka masih sedikit.

\section{Tantangan Desain Pembelajaran Berbasis Kegunaan (Interest-Driven Learning)}

\section{Menciptakan Relevansi}

Pengajar perlu menjabarkan relevansi materi yang diajarkan dengan hal-hal lain yang menjadi minat siswa. Tugas atau aktivitas pembelajaran yang dilakukan karena minat akan membuat siswa terdorong untuk menguasai hal tersebut, bukan hanya sebagai penggugur kewajiban (Edelson \& Joseph, 2004). Diperlukan variasi bentuk tugas agar dapat mengakomodasi berbagai macam minat siswa di luar lingkungan pendidikan.

Terdapat dua strategi yang dapat dilakukan pengajar untuk menciptakan relevansi. Pengajar dapat merancang aktivitas pembelajaran yang dapat dilakukan siswa di luar sekolah yang dapat mengakomodasi minat siswa (Edelson \& Joseph, 2004). Sebelumnya, pengajar dapat melakukan riset terlebih dahulu mengenai minat siswa yang diajar. Kemudian, pengajar memetakan minat-minat tersebut dalam beberapa kelompok besar, yang menjadi bahan pertimbangan dalam merancang aktivitas pembelajaran. Siswa dipersilakan untuk memilih aktivitas dan tugas mana yang sesuai dengan minatnya, sehingga tujuan pembelajaran dapat tercapai dan tidak membosankan. Selain itu, pengajar dapat membebaskan siswa dalam mengerjakan tugas sesuai dengan minat masingmasing. Kedua pendekatan tersebut tetap harus memunculkan kegunaan yang dapat dirasakan oleh siswa (Edelson \& Joseph, 2004). 


\section{Menguatkan Minat}

Salah satu masalah dalam proses pembelajaran adalah kurangnya ketertarikan siswa untuk terlibat dalam aktivitas belajar atau tidak mengeluarkan upaya yang optimal untuk mencapai tujuan pembelajaran (Edelson \& Joseph, 2004). Lemahnya minat siswa terhadap proses belajar bisa jadi karena adanya masalah pada persepsi, fluktuasi, dan ketidaksukaan. Masalah persepsi muncul ketika siswa tidak paham tujuan pembelajaran sampai ia benar-benar menyelesaikannya dan mengalaminya langsung. Di awal pembelajaran, siswa memiliki persepsi bahwa materi yang diajarkan tidak berdampak langsung pada kehidupannya. Maka dari itu, pengajar perlu untuk menyampaikan dengan jelas bahwa materi tersebut dapat diaplikasikan dalam banyak konteks. Selain permasalahan pada persepsi siswa, lemahnya minat juga dapat disebabkan fluktuasi yang terjadi dari waktu ke waktu (Edelson \& Joseph, 2004). Siswa tidak selalu berminat dalam mengerjakan tugas yang diberikan, ada kalanya minat mereka menurun drastis. Terakhir, ketidaksukaan terhadap tugas tertentu dapat membuat siswa kehilangan minat. Rasa tidak suka disebabkan karena banyak hal yang tidak dapat digeneralisasi.

\begin{tabular}{l|l}
\hline Dimensi & Deskripsi \\
\hline Tipe & $\begin{array}{l}\text { Informatif (konsep, analisis, sintesis, deskripsi perangkat } \\
\text { pembelajaran, dan sebagainya. }\end{array}$ \\
Umpan balik/komentar (terhadap tugas siswa.) \\
Panduan (tugas lapangan atau tugas praktik) \\
Materi otentik (interview pengajar tamu, dan lain-lain.) \\
Medium & Audio (podcast pada umumnya) \\
Video (dapat disebut sebagai vodcast) \\
Durasi & Pendek (1-5 menit) \\
Sedang (6-15 menit) \\
Pembicara & Panjang (>15 menit) \\
Pengajar \\
Siswa \\
Pihak lain (ahli, pegiat komunitas sosial, dan sebagainya) \\
Formal \\
Tujuan & Informal \\
Menginformasikan \\
Analisis \\
Mengembangkan \\
Memotivasi \\
Mediasi untuk pembelajaran reflektis \\
Dan lain sebagainya. \\
Berbicara langsung kepada pendengar \\
Tanya jawab \\
Storytelling
\end{tabular}




\begin{tabular}{|c|c|}
\hline \multirow{3}{*}{$\begin{array}{l}\text { Konektivitas materi } \\
\text { lain } \\
\text { Struktur }\end{array}$} & Pengajar mengarahkan siswa pada sumber pembelajaran \\
\hline & Linear \\
\hline & Tidak linear \\
\hline \multirow[t]{4}{*}{ Pendekatan pedagogi } & Pedagogi transmisif \\
\hline & Pedagogi dialogis \\
\hline & Pedagogi konstruksionis \\
\hline & Pedagogi ko-konstruktif \\
\hline Subyek & Materi pelajaran yang akan diajar \\
\hline
\end{tabular}

\section{The Interest-Driven Learning Design Process}

Dalam merancang desan pembelajaran IDLD, terdapat empat tahapan atau fase dilalui (Edelson \& Joseph, 2004). Pertama, menentukan minat siswa. Pada fase ini, pengajar perlu mengakomodasi minat dimiliki siswa dan memaparkan peluang-peluang yang ada untuk menciptakan minat baru pada diri siswa. Kedua, menyesuaikan tujuan pembelajaran dengan minat siswa. Pengajar perlu mengidentifikasi tujuan pembelajaran dan menciptakan relevansi agar siswa dapat mengaplikasikan pengetahuannya pada minat yang dimiliki. Ketiga, jika dibutuhkan, pengajar perlu menyesuaikan konteks motivator untuk memunculkan motivasi siswa. Jika siswa terlihat tidak merasa memiliki relevansi terhadap aktivitas belajar, pengajar perlu menggunakan konteks lain. Keempat, pengajar juga dapat menggunakan konteks motivator untuk menjaga motivasi siswa dalam belajar.

\section{TIPE PODCAST}

Carvalho et al. (Carvalho, 2008) mengklasifikasikan podcast dalam beberapa dimensi yaitu tipe, medium, durasi, pembicara, gaya, dan tujuan. Lalu Fernandez et al. (Drew, 2017b) menambahkan dimensi suara, konektivitas dengan materi lain, struktur, pendekatan pedagogi, dan subyek atau materi yang diajarkan.

Menyusun podcast ternyata tidak cukup hanya dengan panduan dari Carvalho et al. (Carvalho, 2008). Fernandez et al. (Drew, 2017b) menambahkan tiga klasifikasi di antaranya: (1) konteks general dari pembelajaran, (2) esensi podcast, dan (3) karakteristik podcast.

\section{Konteks General}

Pembahasan dalam konteks general mencakup tujuan pembelajaran dan tipe siswa. Pengajar perlu menentukan tujuan umum pembelajaran. Pada konteks pendidikan tinggi, aspek kognitif dianggap sebagai aspek yang difokuskan. Maka dari itu, empat tujuan pembelajaran di bawah ini menyasar aspek kognitif siswa (Drew, 2017b).

Pengetahuan: mengingat data atau informasi.

Komprehensi: Memahami makna, interpretasi, pola-pola dari suatu instruksi dan permasalahan. Pengajar dapat merumuskan permasalahan yang diangkat dalam bahasa yang nyaman digunakan. 
Aplikasi: Menggunakan konsep dalam situasi baru atau pengaplikasian suatu abstraksi. Tujuannya agar siswa dapat mengaplikasikan apa yang telah dipelajari di kelas ke dalam situasi yang baru atau di lingkungan kerja.

Analisis: Memisahkan materi pembelajaran atau konsep ke dalam bagian-bagian dari komponen tertentu sehingga struktur dari meteri tersebut dapat dipahami. Perlu dibedakan antara fakta-fakta yang teruji secara ilmiah dan kesimpulan yang diambil.

Sintesis: Membangun struktur atau pola dari elemen-elemen yang berbeda. Selain itu, tujuan dari pembelajaran ini adalah untuk meletakkan bagian-bagian yang terpisah tersebut dalam satu kesatuan untuk mendapatkan pemahaman baru tentang suatu materi.

Evaluasi: Membuat kesimpulan atas nilai dari suatu gagasan atau materi pembelajaran.

\section{GENRE PODCAST PENDIDIKAN}

Analisis genre banyak digunakan untuk mengetahui cara media menyampaikan informasi dengan cara yang menarik dan dapat dipahami oleh target. Genre bersifat dinamis, berubah-ubah atau berevolusi dengan cara latihan yang dilakukan praktisinya. Formasi genre menyesuaikan dengan karakteristik media baru; mudahnya proses produksi sebagai imbas dari tuntutan para pengguna internet akan konten-konten baru (Bakardjieva, 2005; Guinda, 2015). Fenomena ini sering digambarkan sebagai 'budaya konvergensi' (Jenkins, 2006), di mana bentuk genre lama dari media yang lebih tradisional mengalami perubahan. Garis batas antara produsen dan konsumen menjadi kabur serta membuka intertekstual baru dan interaktif.

Metode umum untuk analisis genre adalah pendekatan 'gerakan' atau move yang diusulkan oleh Swales (Swales, 1990; Tardy, C.M. and Swalles, 2014). Pendekatan gerakan dalam analisis genre ini dianggap sebagai sarana untuk melihat fungsi bagian tertentu dari teks yang dianalisis, lalu kaitannya dengan fungsi keseluruhan (Randy \& Briones, 2012). Dalam praktiknya, analisis ini sering dicapai melalui analisis tiga tingkat genre. Tingkat pertama, diperlukan penjelasan tentang tujuan komunikatif genre, yang merupakan penggunaan umum genre secara genral. Level kedua adalah struktur pergerakan/move yang mencirikan genre, yang merupakan fungsi tekstual konvensional yang diulang-ulang oleh praktisi di seluruh genre-teks. Struktur gerakan sering dapat diidentifikasi melalui tingkat ketiga, yang merupakan analisis dari langkah-langkah retoris yang diambil dalam realisasi gerakan. Contohnya, gerakan dalam genre resep masakan bisa jadi untuk memberikan daftar tindakan apa saja yang harus dilakukan secara kronologis. Retorika umum yang digunakan bisa seperti 'aduk dengan kecepatan sedang'.

Proses pertama dalam analisis teks podcast ini adalah dengan menentukan tujuan umum dari podcast pendidikan (Tardy, C.M. and Swalles, 2014). Setelah itu menentukan desain podcast (Carvalho, 2008; Drew, 2017a) dan pengeditan (Drew, 2017b) termasuk jenis konten, durasi (pendek 1-5 menit; medium 5-15 menit; panjang >15 menit). Penulis 
atau pengisi podcast (guru, siswa atau lainnya), gaya (formal atau informal), tujuan (menginformasikan, merefleksikan, memotivasi, dan sebagainya). Setelah dilakukan proses identifikasi tersebut, muncul tiga genre umum.

\section{The Quick Burst}

'The Quick Burst' menjelaskan bentuk podcast yang tujuan komunikatifnya adalah penyampaian satu informasi yang menjadi kunci secara ringkas. Panjangnya biasanya di bawah 5 menit, dan sangat sering digambarkan sebagai podcast 'satu menit', teks dalam genre ini menyajikan kiat belajar tunggal atau ide-ide kunci untuk pendengar. Genre ini telah diidentifikasi di berbagai bidang pembelajaran, termasuk sains, pembelajaran bahasa, sejarah dan minat umum.

Gerakan 1: Kontrol waktu yang singkat

Teks yang sesuai dengan genre podcast ini umumnya berpatokan pada batasan waktu yang. Pembatasan waktu ini dilandasi adanya survei yang mengungkapkan bahwa minat dan fokus peserta didik dapat dengan cepat berkurang setelah 5 menit pertama (Kidd, 2012; Lee, 2017). Maka dari itu, untuk tujuan pembelajaran yang tidak membutuhkan daya analisis, pengajar perlu membuat podcast yang singat. Kesadaran akan batasan waktu dibuktikan dengan merujuk pada singkatnya judul podcast. Hal ini juga dapat menjadi perkiraan waktu yang dibutuhkan siswa yang akan mendengarkan.

Genre ini cocok untuk menginformasikan fakta-fakta yang hanya butuh waktu singkat untuk memahami dan mengingat. Sebagai alat kognitif, podcast dengan genre The Quick Burst dapat berfungsi untuk membantu peserta didik dalam refleksi mereka atas konten yang dipelajari sebelumnya. Namun, pembelajaran yang lebih dalam atau dengan tujuan meningkatkan keterampilan pemecahan masalah tidak bisa melalui podcast yang berdurasi 1 hingga 5 menit. Karena itu, genre 'The Quick Burst' harus melihat tujuan utama, yang sebetulnya dirancang untuk pemanasan, ringkasan atau keterlibatan siswa dalam mengingat kembali materi sebelumnya.

\section{Gerakan 2: Bouyancy atau daya apung}

Daya apung menjelaskan bagaimana pengajar menarik perhatian pendengar (Drew, 2017a). Melalui nada bicara yang dimanipulasi sedemikian rupa, pembawa acara atau host podcast berusaha untuk menarik atensi pendengar secepat mungkin, karena durasi podcast yang relatif singkat. Cara-cara yang dapat dilakukan adalah menajamkan ucapan dengan artikulasi yang sejelas mungkin, cepat, dan dibawakan dengan optimisme yang tinggi. Pembawa acara seminimal mungkin mengambil jeda dan memanfaatkan satu tarikan napas untuk menyampaikan informasi dengan padat. Prinsipnya, dapat menyampaikan informasi semaksimal mungkin dengan waktu yang seminimal mungkin.

Pembawa acara juga dapat menyertakan lagu sebagai musik latar untuk mendukung podcastnya (Drew, 2017a). Layaknya siaran di radio, musik yang tepat akan membantu pendengar untuk meningkatkan kesiapan dalam mendengarkan podcast 
dengan genre The Quick Burst. Musik yang menjadi latar biasanya lebih lembut agar tidak mengganggu pembawa acara yang sedang menyampaikan informasi dengan padat dan cepat. Nada maupun teks yang diucapkan oleh pembawa acara podcast The Quick Burst lebih mirip dengan iklan di televisi atau segmen berita.

Banyak pengajar yang khawatir kehilangan perhatian siswa karena merasa bosan mendengarkan podcast. Oleh karena itu, genre ini dapat dijadikan alternative untuk menghasilkan pesan yang jelas dan ringan bagi siswa. Tujuan genre pendidikan The Quick Burst ini memang untuk menarik para siswa ke dalam pengalaman belajar dan menghidupkan pembelajaran online (Drew, 2017a). Selain itu, singkatnya podcast memungkinkan untuk dipublikasi dengan lebih teratur, misalnya setiap hari. Pembuatan konten selama maksimal 5 menit tidak terlalu menyita waktu sehingga dapat dipublikasi dengan lebih disiplin.

Namun, podcast dengan genre The Quick Burst ini tidak membutuhkan keterampilan tingkat tinggi seperti analisis dan evaluasi (Drew, 2017a). Podcast 'Quick Burst' tidak memiliki kerangka waktu yang cukup untuk menggali lebih dalam tentang ide-ide pokok yang disajikan. Hal ini sangat membatasi potensi podcast tersebut untuk melakukan pengayaan informasi atau konten.

\section{The Narrative / Narasi}

'Narasi' memiliki tujuan komunikatif untuk bercerita dengan lebih mendalam tentang suatu topik. Penggunaan narasi dalam podcast sejarah telah digambarkan sebagai suatu kombinasi antara format episodik siaran radio dan rasa liveness. Tipe narasi membuat pendengar dapat membayangkan atau visualisasi suatu peristiwa sejarah yang sedang diceritakan. Format podcast dengan genre Narasi berdurasi relatif panjang dan suara narasi buku cetak atau audio' (Salvati, 2015). Perpaduan narasi nada radio dan buku audio menunjukkan bahwa model genre ini sebetulnya juga dapat ditemukan pada media lain. Namun, genre ini menghadirkan keunikan dengan menggabungkannya dalam satu siaran podcast.

\section{Gerakan 1: Mendongeng}

Langkah pertama dan utama yang menjadi ciri podcast ini adalah mendongeng. Sebuah cerita berfungsi sebagai fitur utama dari genre Narasi ini. Biasanya, podcast dengan genre ini audio berdurasi 40-80 menit. Berbeda dengan genre The Chat Show, yang dibahas kemudian dalam bagian ini, The Narrative melibatkan pendongeng yang berkelanjutan secara langsung dari pendongeng ke pendengar. Podcast ini juga tidak terlalu banyak jeda atau sedikit istirahat dalam narasi untuk diskusi bentuk bebas. Hal ini memungkinkan pendengar dapat merasa bosan dan sulit untuk mengetahui klimaks atau inti dari suatu kisah yang diceritakan.

Untungnya, dengan adanya fitur jeda, mundur, dan penyimpanan, podcast tersebut dapat didengar ulang baik secara keseluruhan atau dalam segmen tertentu. Fitur ini sangat 
berguna untuk membantu siswa dalam membuat catatan dan mendengarkan lagi sebelum ujian. Dalam hal ini, podcast membantu peserta didik dalam terlibat dengan pelajaran di waktu mereka sendiri dan dengan kecepatan mereka sendiri untuk menguatkan materi pembelajaran.

Sebetulnya, cerita-cerita dalam genre 'Narasi' lebih dari sekadar menyajikan informasi baru kepada pendengar atau bahkan sekadar 'menghibur' audiensnya (Drew, 2017a). Ada kekuatan afeksi yang dapat dihadirkan dalam genre ini. Melalui pemilihan kata-kata, yang dibuat menjadi rangkaian suatu kisah, dapat meumbuhkan sisi emosional pendengar. Durasi yang dibuat lebih panjang menjadi peluang bagi pembuat konten untuk dapat membuat podcast genre ini menjadi lebih asyik dan mengesankan.

\section{Gerakan 2: Signposting dan cross-linking}

Penjelasan sebelumnya menggambarkan bahwa dongeng atau kisah menjadi fitur utama dalam genre Narasi. Namun, ada juga fitur karakteristik lain dari genre ini yang mendukung fitur utama. Fitur pendukung ini adalah penggunaan penunjuk arah (signposting) dan hubungan silang (cross-linking). Cross-linking melibatkan hubungan antara podcast dalam suatu seri untuk mengembangkan hubungan kognitif antara konten pelajaran di seluruh unit atau seri podcast. Strategi cross-linking ini terbukti dalam berbagai teks media baru yang menggunakan keterkaitan dengan internet untuk menambah kedalaman penceritaan. Pengajar dapat memandu siswa atau pendengar untuk melakukan aktivitas atau langkah tertentu untuk mendapatkan gambaran yang lebih komprehensif. Misalnya, pembawa acara dapat meminta pendengar untuk mencari suatu informasi dengan kata kunci tertentu, klik fitur yang dimaksud, dan sebagainya. Melalui cross-linking, podcast dapat mendukung siswa dalam memahami konten pelajaran dengan menggambarkan secara verbal.

Signposting dan cross-linking, walaupun mungkin sudah terbukti dampaknya di media terkait seperti seri radio atau bahkan kuliah langsung, ternyata juga memiliki keunikan dalam podcast. Siswa dapat berhenti, mundur, atau kembali ke podcast sebelumnya sesuka hati. Fitur-fitur ini dapat membantu dalam mengembangkan lingkungan belajar yang kaya dan konsisten. Signposting dan cross-linking dapat memfasilitasi siswa atau pendengar untuk menciptakan pengalaman belajar pribadi (Madsen \& Potts, 2010). Mereka juga dapat belajar dengan kecepatan mereka sendiri: bisa bolak-balik, berhenti sebentar untuk memikirkan informasi yang didengar, mencatat penanda waktu untuk kembali ke segmen nanti dan seterusnya. Dalam genre 'The Narrative', semua fitur baik yang utama maupun pendukung, bersatu untuk menciptakan bentuk genre unik yang mendukung e-learning menjadi menarik, emosional, dan mandiri. 


\section{The Cat Show}

Tujuan komunikasi genre Chat Show adalah pemanfaatan percakapan yang dilembagakan antara dua atau lebih peserta untuk mengeksplorasi berbagai ide dan konsep. Definisi tujuannya ini dipinjam dari diskusi (Ames, 2016) tentang acara obrolan radio. Ames menjelaskan acara obrolan sebagai melibatkan percakapan yang dilembagakan, karena 'terjadi karena alasan tertentu, dengan masing-masing pembicara menempati posisi tertentu (Ames, 2016) seperti 'host' dan 'tamu'.

Meskipun acara obrolan radio sangat dekat, seri podcast dalam genre ini cenderung lebih spesifik untuk membicarakan topik tertentu (Ames, 2016). Hal ini dapat terjadi seperti yang dikatakan oleh Wrather (Wrather, 2016) bahwa target podcasting kelompok penggemar kecil tapi spesifik berdasarkan pada kepentingan komunitas. Obrolan pada The Cat Show berbeda dengan obrolan yang ada di radio yang bertujuan untuk menyiarkan massa.

\section{Gerakan 1: Percakapan}

Elemen kunci dari genre The Cat Show yang bertentangan dengan genre yang tercantum di atas, adalah dialog di antara anggota panel alih-alih sebagian besar audio host tunggal. Secara pedagogis, percakapan antara panel dari beberapa presenter yang terlibat dalam percakapan institusional memiliki potensi untuk melibatkan pendengar dalam keterampilan berpikir tingkat tinggi seperti analisis dan sintesis, tidak seperti podcast dengan genre The Quick Burst yang lebih pendek.

Percakapan berkelanjutan ini pada istilah dan ide-ide kunci tidak hanya model pemikiran kritis tetapi juga konvensi bahasa dalam komunitas wacana ilmiah (Ames, 2016). Podcast ini dengan demikian memiliki kapasitas untuk mendukung pembelajaran dengan menempatkan bahasa logam ke dalam konteks percakapan dan memodelkan bentuk dan fungsinya dalam situasi bahasa sehari-hari.

\section{Gerakan 2: Kecerdasan}

Pentingnya hiburan sudah dibahas dalam ketiga genre podcast yang dijelaskan sebelumnya. Namun, The Cat Show memiliki kelebihan dibanding genre yang lain. Selain menyasar kecerdasan, 'The Chat Show' muncul sebagai genre yang paling memungkinkan untuk membuat pendengar tertawa. Istilah 'cerdas' menggambarkan langkah ini untuk menekankan perpaduan antara humor dan intelektualisme. Sekali lagi mengikuti Ames, genre ini mengambil dari kemampuan yang dimiliki radio untuk "mengobrol" menjadi campuran kompleks dari lelucon dan yang serius (Ames, 2016). Seringkali, pengajar dengan genre The Cat Show ini memperkenalkan diri sejak awal sebagai komedian atau ilmuwan.

Penggunaan genre kecerdasan The Chat Show cenderung berfungsi sebagai sarana yang tidak hanya untuk hiburan tetapi juga sebagai alat kognitif untuk pembelajaran siswa. Lelucon menjadi anekdot yang mudah diingat dan menarik yang memanusiakan isi pelajaran dan menempatkannya dalam bentuk cerita. Sebagaimana 
(Egan, 2001) menjelaskan bahwa menempatkan konten pembelajaran ke dalam bentuk bercerita seperti dalam lelucon memungkinkan peserta didik untuk 'mencari makna afektif dan menghadirkan sisi emosional dalam konten' untuk memungkinkan peserta didik mengingat cerita manusia daripada fakta saja. Informasi yang melibatkan emosi hingga tertawa akan masuk ke dalam memori jangka panjang. Konten pembelajaran yang disampaikan dalam bentuk narasi lucu akan diingat pendengar dalam jangka waktu yang cukup lama.

\section{SIMPULAN}

Penelitian mengenai podcast di Indonesia perlu dikembangkan lebih dari seputar manfaatnya dalam konteks pendidikan. Apalagi, podcast dapat menjadi alternatif yang efektif dalam menyampaikan materi pembelajaran jarak jauh. Untuk dapat memberikan dampak positif bagi siswa, pengajar perlu mempertimbangkan desain saat akan membuat podcast. Melalui panduan desain podcast yang telah dijelaskan dalam artikel ini, pengajar dapat memadukan desain podcast dari IDLD, tipe podcast dari Fernandez et al. (Drew, 2017b) serta jenis podcast dari Drew (Drew, 2017a).

IDLD (Edelson \& Joseph, 2004) menekankan pentingnya mengakomodasi minat siswa dalam proses pembelajaran agar siswa terdorong untuk menguasai materi yang diajarkan. Saat merancang materi pembelajaran yang akan disampaikan melalui media podcast, pengajar dapat menjadikan IDLD sebagai panduan. Selain itu, tipe podcast yang disempurnakan oleh Fernandez et al. (Drew, 2017b) juga dapat dijadikan pertimbangan baik dalam menentukan durasi waktu, gaya yang digunakan (formal atau informal), tujuan yang hendak dicapai dalam episode tertentu, dan sebagainya. Lalu, pengajar juga dapat mempertimbangkan penyampaian podcast melalui framework jenis podcast dari Drew (Drew, 2017a).

\section{DAFTAR PUSTAKA}

Alexander, M.P. (1995). A Multidisciplinary Approach to Anterior Attentional Functions. Annals of the New York Academy of Sciences, 769(1), 191-212. https://doi.org/10.1111/j.1749-6632.1995.tb38140.x

Ames. (2016). Talk vs chat-based radio: A case for distinction. Radio Journal, 14(2), 177-191. https://doi.org/10.1386/rjao.14.2.177_1

Ames, C. (1992). Ames 1992.Pdf. In Journal of Educational Psychology (Vol. 84, pp. 261-271).

Ann Renninger, K. (2000). Individual interest and its implications for understanding intrinsic motivation. Intrinsic and Extrinsic Motivation, 373-404. https://doi.org/10.1016/b978-012619070-0/50035-0

Bakardjieva, M. (2005). Internet society: The internet in everyday life. Internet Society: The Internet in Everyday Life, 1-220. https://doi.org/10.4135/9781446215616

Bonini, T. (2015). The listener as producer: the rise of the networked listener.

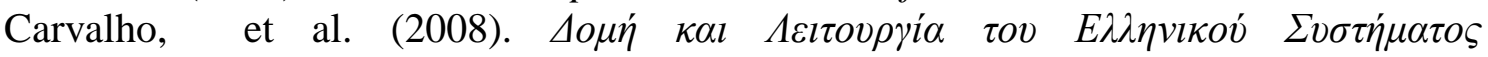

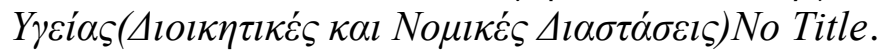

Darwis, R. (2016). Students ' Perceptions towards the Use of Podcast in Learning English : a Case Study of the Second Grade Students At One High School in Bandung. Journal of English and Education, 4(2), 80-100. 
Drew, C. (2017a). Educational podcasts: A genre analysis. E-Learning and Digital Media, 14(4), 201-211. https://doi.org/10.1177/2042753017736177

Drew, C. (2017b). Edutaining audio: an exploration of education podcast design possibilities. Educational Media International, 54(1), 48-62. https://doi.org/10.1080/09523987.2017.1324360

Edelson, D. C., \& Joseph, D. M. (2004). The interest-driven learning design framework: motivating learning through usefulness. ICLS '04 Proceedings of the 6th International Conference on Learning Sciences, 60208(1), 166-173.

Egan, K. (2001). Why education is so difficult and contentious. Teachers College Record, 103(6), 923-941. https://doi.org/10.1111/0161-4681.00139

Guinda, C. S. (2015). (Linguistic Insights 191) Ruth Breeze, Maurizio Gotti, Carmen Sancho Guinda (eds.

Hannover, B., \& Kessels, U. (2004). Self-to-prototype matching as a strategy for making academic choices. Why high school students do not like math and science. Learning and Instruction, 14(1), 51-67. https://doi.org/10.1016/j.learninstruc.2003.10.002

Kidd, W. (2012). Utilising podcasts for learning and teaching: A review and ways forward for e-Learning cultures. Management in Education, 26(2), 52-57. https://doi.org/10.1177/0892020612438031

Lee, M. J. W. and T. (2017). Podcasts and distance learning Chapter 9 : Podcasting to support distance learning. June.

Madsen, \& Potts. (2010). Voice cast: the distribution of the voice via podcasting' in Voice: Vocal Aesthetics in Digital Arts \& Media, (Eds. Norie Neumark, Ross Gibson and Theo Van Leeuwen. MIT Press.

Randy, R., \& Briones, Y. (2012). Move Analysis of Philosophy Research Article Introductions Published in the University of Santo Tomas. Philippine ESL Journal, 9(July), 56-75.

Rizky Widodo, M., \& Gunawan, A. (2019). Investigating the Effect of Using Podcast on Students' Listening Comprehension. Lingua, 15(2), 35-42. https://doi.org/10.34005/lingua.v15i2.358

Salvati, A. J. (2015). Podcasting the Past: Hardcore History, Fandom, and DIY Histories. Journal of Radio and Audio Media, 22(2), 231-239. https://doi.org/10.1080/19376529.2015.1083375

Schiefele, U. (1991). Interest, Learning, and Motivation. Educational Psychologist, 26(34), 299-323. https://doi.org/10.1080/00461520.1991.9653136

Soerjowardhana, A., \& Nugroho, R. A. (2017). Developing English Job Interview Skill by Self-Access Language Learning through Audio Podcast-Based Learning Media. Celt: A Journal of Culture, English Language Teaching \& Literature, 17(2), 179. https://doi.org/10.24167/celt.v17i2.1115

Swales, J. M. (1990). Swales, J. (1990). Genre analysis.

Tardy, C.M. and Swalles, J. M. (2014). Genre analysis (Vol. 3, Issue 2).

Wrather, K. (2016). Making Maximum Fun for fans. The Radio Journal - Internacional Studies in Broadcast \& Audio Media, 14(1), 43-63. https://doi.org/10.1386/rjao.14.1.43

Wulan, O. R. N. (2018). the Effect of Implementing Podcast in Enhancing Students' Speaking Achievement in the Fully Digital Era. PEOPLE: International Journal of Social Sciences, 3(3), 1173-1185. https://doi.org/10.20319/pijss.2018.33.11731185 
http://ejurnal.pps.ung.ac.id/index.php/Aksara

Yoestara, M., \& Putri, Z. (2019). PODCAST: An alternative way to improve EFL students' listening and speaking performance. Englisia Journal, 6(1), 15. https://doi.org/10.22373/ej.v6i1.3805 